\title{
Cairo: Personal Reflections on Enduring Daily Life
}

\author{
MONA ABAZA
}

\section{Tale I}

\section{Meanderings and wanderings through regular commutes to the desert}

In Palm Hills we dream of the return of love and beauty... and clear enjoyment... and the return of mercy to our heart... and the dream of the return of culture and the arts.... And enlightened thought.... Palm Hills for construction... the return of the Egyptian spirit (Advertisement on ONTV channel, during Ramadan, June 2016).

"La Vie en Rose" located in the $5^{\text {th }}$ Compound Service Center, New Cairo.

"La Vie en Vert." Villette New Cairo, SODIC. For more information, visit us at the SODIC Sales Center Headquarters km 38 Cairo-Alexandria Desert Road.

"La Vie en Vert" is an advertisement I encounter on a daily basis on the depressing desert road that takes me to my simulated-like shopping mall-cumAmerican University campus located in the eastern desert of New Cairo. The commute is about fifty kilometers one way, thus about one hundred kilometers round-trip. For an American such a commute might not be an issue at all, were it not been for the deadly interminable traffic jams paralyzing the city on a daily basis. One could easily argue that the chief predicament of modern Egyptians today is that they waste almost half of their lives in commuting from one end of the city to the other. Not only that, one way of defining who belongs to the working class today in Egypt is through their means of transport and whether the commuter uses three different means of transports to reach one

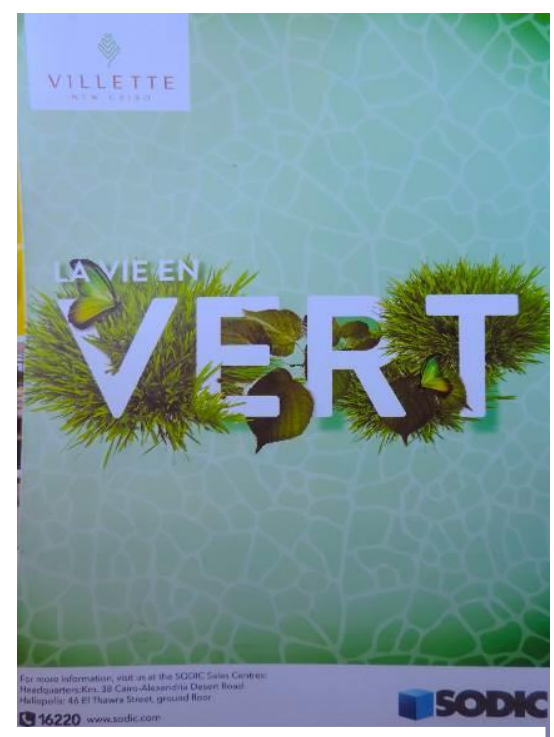

Visions of a daily commute Fig. 1: SODIC La Vie en Vert

1 [Editor's note: Here and in the following, terms emphasised in bold indicate artifacts, roles and activities that with all probability will be of particular relevance for the In 2016 project's search for Gumbrecht'ian arrays, codes, and codes collapsed (cf. S. GUTH's Introduction to the present Living 2016 dossier). The emphasis is the editor's.] 
destiny on daily basis - public buses, micro buses, collective taxis, the metro, and tuctucs - to reach their destination. (See photos 1 and 2).

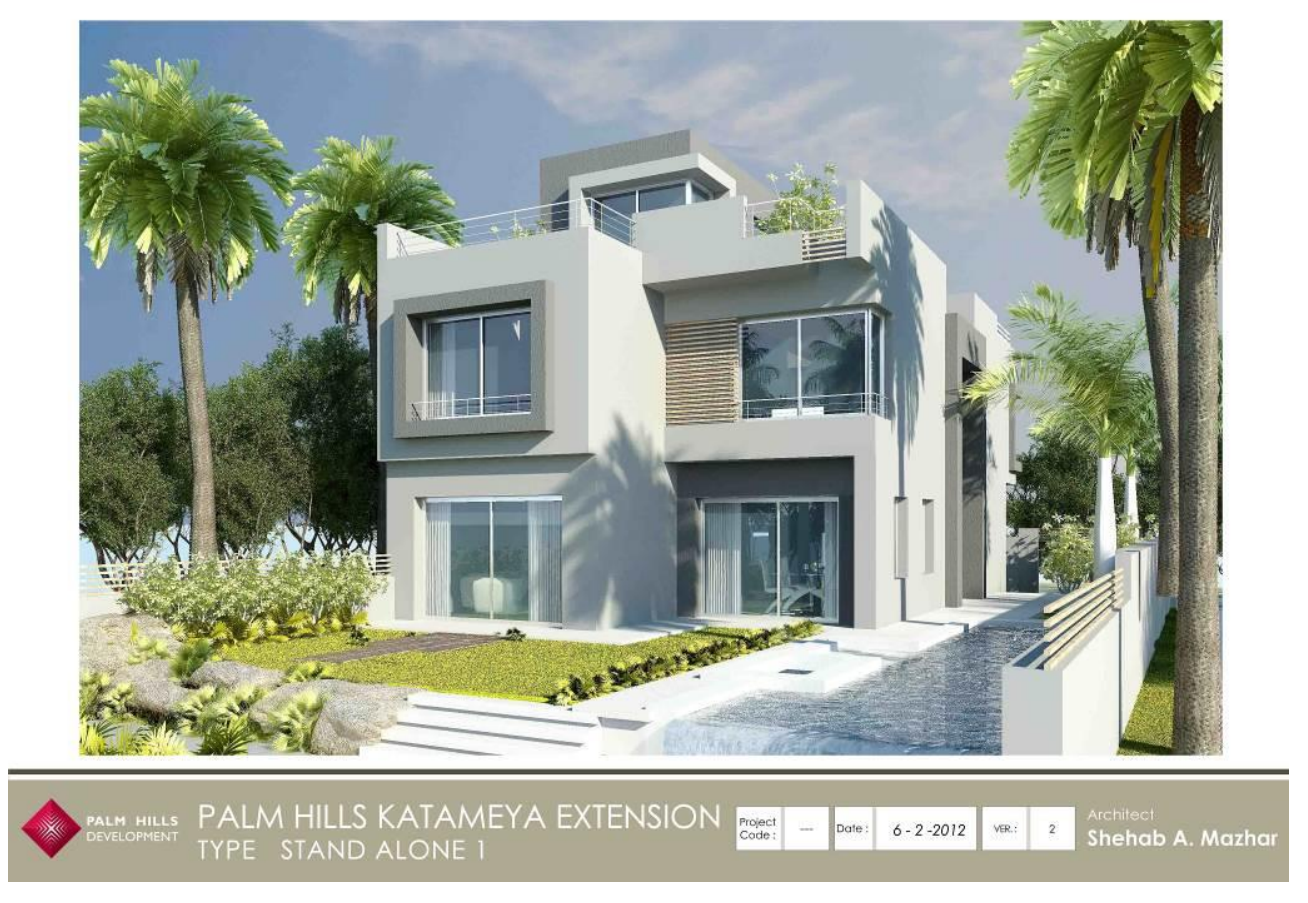

Visions of a daily commute

Fig. 2: Stand-alone for sale in Village Garden Katameva £E 3.670.000

The construction costs of the 260 -acre campus, inaugurated in 2008 , rocketed to some $\$ 400$ million. $^{2}$ The idea was to hybridize elements of Islamic architectural traditions into modern lines, which succeeds as a first impression. It seems, however, that functionality was neglected by that colossal construction's designers. Eight years have not been sufficient to conciliate my alienation from the new campus. At the start of every semester, I have trouble finding my classes. I keep on constantly doubting about myself. Am I ageing prematurely? Perhaps I am suffering from an everlasting disorientation that has to do with a continuous erasure of memory, inflicted on me by the powers that be and I keep on wondering whether this is becoming a national collective exercise. My nostalgia and sense of loss towards the old Tahrīr Campus where I grew up and taught for many years has been growing by the year. But the Tahrīr campus has been altered too and the Cairo I grew up with no longer exists.

2 <http://www.aucegypt.edu/about/visitor-information/new-cairo-campus> (accessed 8 September 2016). 


\section{Day in, day out indoctrination}

Grab your last opportunity for clean air... Grab the last place in heaven... Invest in the clean and beautiful life of the compounds of upscale New Cairo. We provide you with your dream villa and a swimming pool... All you need is to sign a down payment.... Pay a seven years installment to be in paradise... Choose a worthy life in a gated compound... You deserve a more beautiful life...

These sentences are witch-hunting me everywhere, on billboards, in newspapers, on television and last but no least they are sent repeatedly as messages on my mobile phone. Villas, villettes, condos and compounds....

"You deserve a decent life"... This is an advertisement I read somewhere. But what's a decent life today in Cairo? My Facebook account is constantly invaded by advertisements for lavish villas and walled-off condominiums worth millions, which I cannot afford anyway. And who cares? The last thing I would want is to live in such walled-off spaces among neighbours I would certainly dread. Billboards after billboards selling virtual dreams... Because life at the heart of Cairo has turned into hell. Truly unsustainable. How long can disposable humanity remain disposable?

We all know that human life here is cheap and worthless, but this is certainly no novelty. I know... I know that I am still quite privileged. Above all I am not a political activist... I do not really fear forced disappearance, or incarceration since I am not the clearly targeted age group by the authorities. I am in fact too old to be a suspect by the regime, neither am I really fearing torture or death or being asphyxiated in a police truck by tear gas, as it was the dramatic case in August 2013. ${ }^{3}$ Nor do I fear being banned from travel, as has been the case for a number of human rights activists, journalists and critics of the military regime. ${ }^{4}$ But who knows? Big Brother is expanding by the day.

I am perplexed at how a-political I have become in the last two years. More disturbing is that being a-political does not make life easier, neither does it solve the problem of an infernally chaotic daily life under authoritarian rule and the mounting corruption scandals which confirm vertiginous, unbridled disasters of food, air and water pollution, day after day. However, I often speculate about potential, but all too possible, car accidents on my daily ride... The depressing ring road leading to the new campus is lined with endless redbrick slums and then ugly and cheap high-rise buildings.

But, but... "'We' are fortunate, we are not Syria or Libya, we have managed to avoid a civil war and remain as the only secure oasis in an abysmal region", as countless taxi drivers, several low income publics and above all, the well-off fulūl class (the proMubārakists), keep on constantly saying over and over, perhaps as a self-conviction strategy that life has to go on. Even if one lives by endurance, even if life is unbearable, is not stability irreplaceable? Have we not seen how hard it is to experience the turmoil and violence of revolutions? But what is harder: Revolutions or slow torture in daily life?

3 See KingSLEY 2014.

4 On the question of chasing and harassing intellectuals and activists resulting into a massive exodus, see 'ABD AL-'AZIZ 2014. 


\section{Cairo, early 2016}

January 2011 is so remote, almost like a mirage. Has Taḥrīr been completely deleted from our memory? An endless growing sense of loss and desolation reigns in my surroundings;

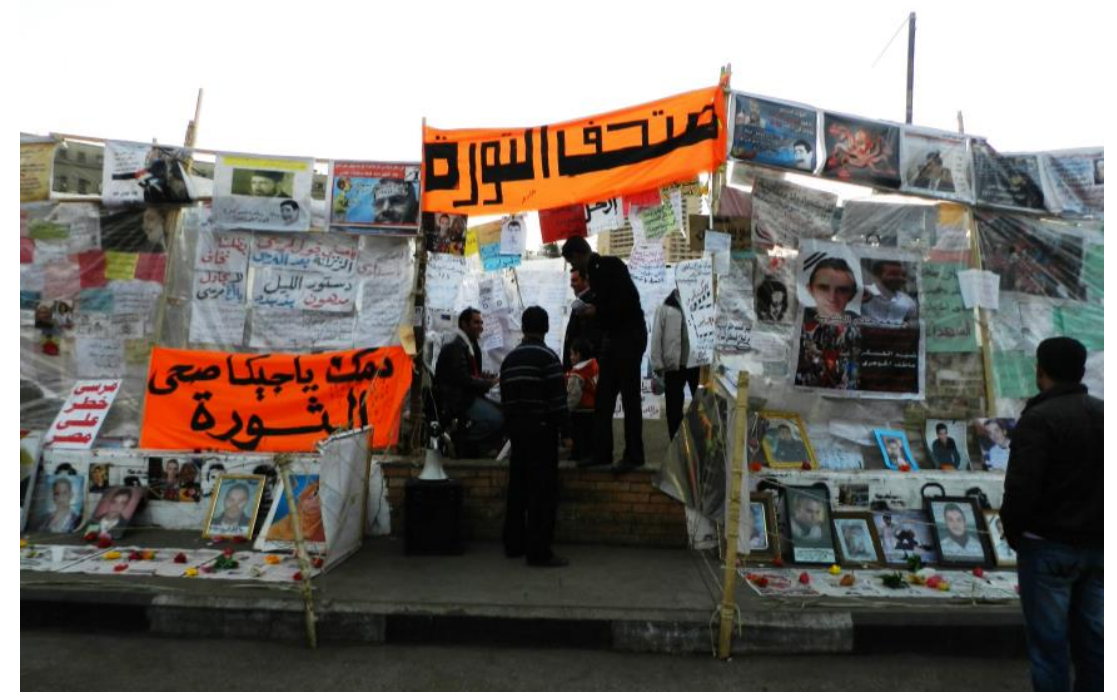

Fig. 3: Museum of the Revolution in Tahrīr. Captured 12 December 2012

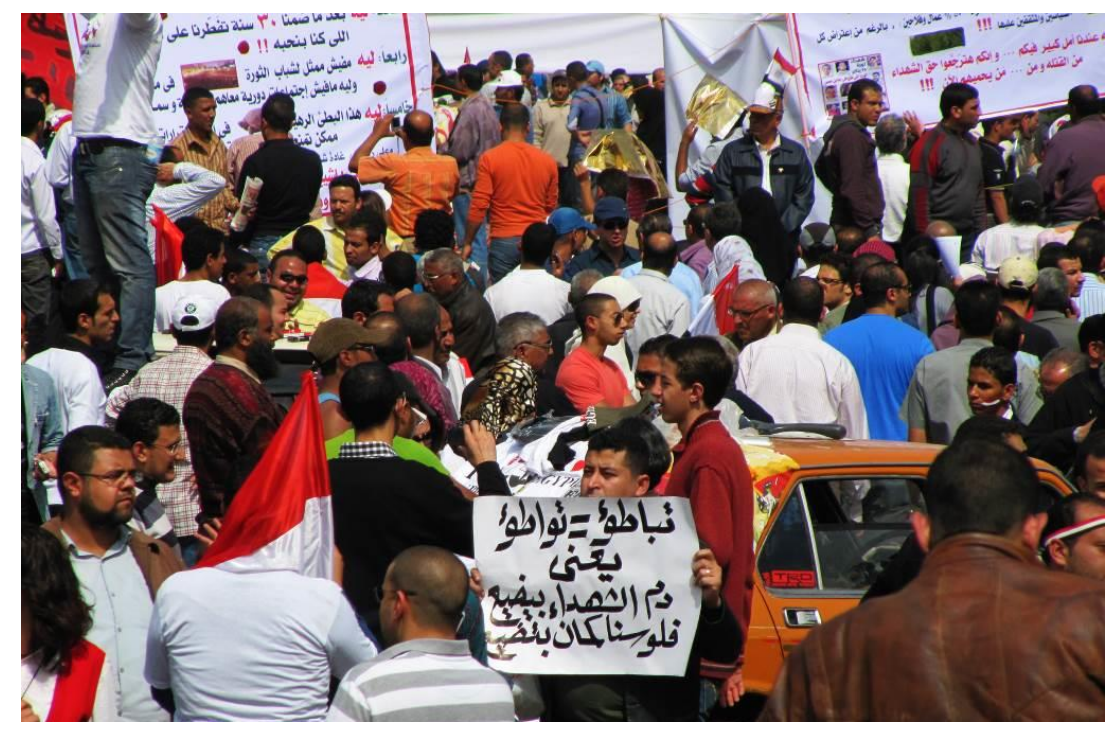

Fig. 4: Tahrīr. Captured 1 April 2011 


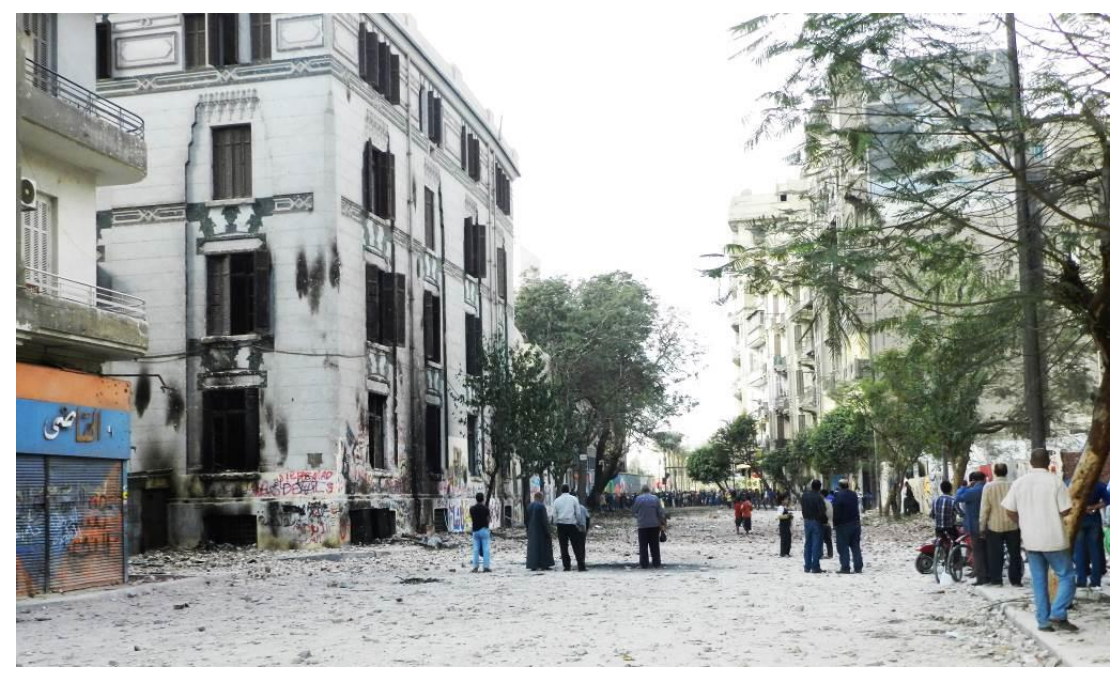

Fig. 5: Violent Incidents of Muhammad Maḥmūd, Captured 23 November 2012

Tahrīr has been reduced into a nostalgic and utopian memory among those who have experienced it. ${ }^{5}$ This nostalgic moment translates naturally into a constant struggle to retain, if not freeze memory, even if it is painful and sad, since it is coupled with an eager-

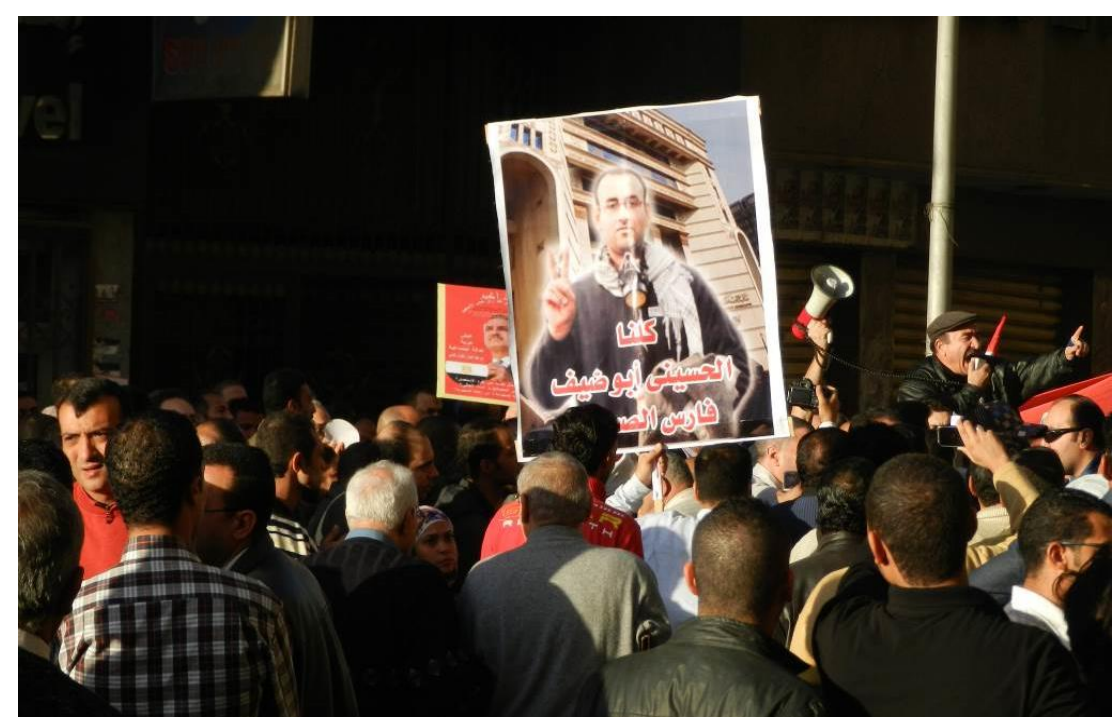

Fig.6: Tahrīr, March mourning journalist al-Ḥusaynī Abū Ḍayf, killed in December 2012 during the Ittihādivva Demonstrations. Cantured 7 December 2012

5 On the question of growing nostalgia and the sense of loss with respect to the revolution, see the ABOU EL-NAGA 2015.

$J A I S \cdot 16(2016): 234-252$ 
ness to record and archive the unfolding events of the past five years, as many have been attempting to hopelessly do. That might also explain why there is an urge to recall, invent and re-invent the "lieux de memoire" (Pierre Nora) ${ }^{6}$ of the past five years' turmoil (see figs. 3-6). This effort is coming to be seen almost as a calling in order to stop the withering away of a vivid memory. Such is the fate of counter-revolutionary moments. Once again, we have been royally overpowered. The dream of change, and the possibility of dreaming, was just a dream turned into a nightmare. This translates into bipolar and pessimistic, if not bleak sentiments. But the present consists of a hard, counter-revolutionary, ruthless moment. The old regime has never really departed. The wounded counter-revolutionary powers that have learned the lesson; Tahrïr is not repeatable and our present is not quite exactly identical to Mubārak's time. It is certainly much worse.

\title{
Tale II
}

\section{Internal migration, or: The flight to the gated communities?}

\author{
... For counter-revolution - the word having been coined by Condorcet in \\ the course of the French Revolution-has always remained bound to revo- \\ lution as reaction is bound to action.
}

Hannah Arendt, On Revolution, 1963 [1990]: 18

Internal migration? Or when to decide to leave in favour of Exodus, to leave this nightmare for good? So many people I know have already left the country, not to mention some of the young activists who keep on leaving, one after the other. It looks as if I will never have the nerve to leave Egypt once more for good. ${ }^{7}$ I seem to be in denial of my past, I have already migrated once to the North, determined to never come back and did come back nonetheless. How archetypal is this return to one's roots or origins after the classical, colonial/post-colonial, Ulyssean experience of traveling overseas for the sake of learning?

I seem to be eternally attached to Egypt, for without doubt, this country has been my endless source of inspiration. But is there an inspiration without suffering and endurance? "So what's your problem?" my friends would say, who have to struggle through endless queues in front of the various embassies to obtain short-term visas. "You are privileged to be able to leave whenever you want."

Some of my acquaintances, who, just like me, are caught in the dilemma of escaping Cairo's inferno, repeatedly tell me: "We all seem to be bound to follow the urban exodus to the desert. It is the only exit for clean air. Go with the better off to the newly built satellite cities." New Cairo in the eastern desert, Sheikh Zayed, City View, the ever expanding projects of SODIC in both the eastern and western deserts, or the Sixth of October City in

6 NORA 1989

7 It is no coincidence that in this special dossier Elena CHITI refers to the burning question of exile and homeland in relationship to contemporary fiction. 
the western desert, and I have had several students find that their quiet residences on the Cairo-Alexandria desert road that have turned into a densely urbanized area. I cannot help perceiving such an exodus but as speeding up the already nightmarish dystopia I am confronted with regularly. I cannot help thinking that in one of my writings, I once called New Cairo in one of my writings the 'ashwä'iyyāt (the slums) of the rich and I still perceive it as such.

Could my utter distaste for the so-called upscale New Cairo simply stem from my elitist hallucinations. Snobbism perhaps? But if this is Cairo's future, then I certainly don't want to get old here. The schizophrenic aesthetics and the alienating architecture of New Cairo lead me to believe that this must be a conscious erasure of reminiscence. For me at least my past life-world has withered away and my sense of loss is growing by the day, with each commute to the new campus. These desert landscapes of unfinished, mushrooming hideous constructions I encounter on my daily commute, after crossing the city slums via the Sixth of October flyover, clearly have little to do with the old Cairo I grew up in. I am far from saying that there were no slums in earlier times. I recall quite well what the poor decrepit neighborhoods looked like some four decades ago, and I know, too, that poverty hurts. However, the architectural ugliness induced by quick money and wealth have become a rule, exacerbating the atrocious space/class divide of the city. Time and again the sense of alienation is renewed.

Coming from the center of town, after leaving the Sixth of October bridge, the traveler enters the gigantic and extended zone of the army barrack. One can observe some of the army's industries, the bottled water and soft drinks factories, and privatized spaces, which include their clubs, hotels, the Air Force stadium and endless desert land that we are told is managed by the army. The military area starts at Nașr City after, just beyond the Sixth of October Bridge. It is followed by the desert with its endless billboards and countless unfinished so-called luxurious, walled-off cities, gated communities, and condos.

After the new flyover, recently constructed by the army, one drives along the famed alShāric al-Tis'in (Road 90). This iconic but otherwise nameless road is the symbolic aperture to the future Cairo, the New upscale Cairo, with its large shopping complexesincluding the gigantic Cairo Festival Centre-its endless office spaces, villas, villettes and gated communities of the rich. This landscape looks like a déjà-vu copy / cityscape, but of a much worse quality, that I have seen, perhaps in Kuala Lumpur, because it reminds me of the relatively new satellite quarter of Kuala Lumpur called Bandar Utama, where I have once lived for half a year. In reality, in a couple of years, Road 90 will once again look like a replica of earlier Nașr City in its earlier days. Originally, Nasr City was a military zone overflowing with army barracks. It eventually evolved into the then new and modern postcolonial satellite city constructed under Nasser, and today it is an agony of unbearable traffic jams, mushrooming shops, and wild, falling-apart construction.

Road 90 quickly evolved into a loud and busy highway with once again interminable traffic jams, as if Cairene city planners excel in replicating the same unresolved problems in each newly-built satellite city. As the French would say, these newly constructed replicas are the best example of la fuite en avant (the headlong rush forward). If the traffic jams are just as hellish on Road 90, why leave the center and move so far away to the desert? On the right side, once again, sticking to each other and competing in ugliness, one large villa after another and two or three-story buildings; on the left side, offices, 
shopping malls, banks, and endless spaces for business. Every morning I ask myself who these lunatics are, who have given away millions for these monstrosities that are just a few meters away from the daily movement of thousands of vehicles. But being located along a lousy highway for the newly rich equals to being modern and moving rapidly towards one's destination.

Since the campus moved in 2008, the commute I confront is a nightmare, not only for being stuck in a bus or a car for hours, but even more because the alienating aesthetics that depress me. These horrific grotesque larger-than-life villas of the nouveaux riches, glued next to each other, filled with fake quasi-Roman columns, and - noblesse oblige- jammed with flowered wrought iron gates, replicating everywhere, make me say time and again melancholic. It is a sin that these villas fill up all the space that could have surrounded them with gardens or greenery. Then, just a few kilometers before I reach the campus, there is the surreal Future University with its kitsch pseudo-Roman construction. Kitsch following more kitsch seems to be the destiny of so called "modern" New Cairo.

This dystopia might not be seen as such by the younger generation and strangely enough, the 2011 Tahrīir effect did not manage to undo it. But, purchasing real estate in New Cairo is a good investment, everyone tells me, "you can simply double the price in a couple of years". Real estate never loses value in Egypt, we are told. How many people in my own circle did that? I remain, with only a few of my friends, in the weird minority that remains solid in the center.

The commute time and again. Interminable, unbearable commutes. I choose another road, but it is worse. The routine of being stuck on the Sixth of October Bridge. Constantly dreaming to flee the country? The militarization of the urban downtown after the bloody incidents of the Muhammad Maḥmūd Street fits together perfectly with the gentrification of another part of the city. Walls and more new walls around the ministries, embassies and the security offices, making it impossible to move in the city.

If the main benefit of the rich is that people can easily plan their life through assets and reserves, which then turn for them into a 'natural' device for predicting and thus efficiently shaping the future, this is exactly why the mindset of the poor is mainly caught in the spiral of fatalism. The hardship of everyday survival implies that one can never really be able to predict or plan much, particularly about where to live. Yet, what makes the uniqueness of Cairo's urban texture is that even if one is considered to be among the well to do, one can never really predict how the residential quarter so 'rationally' chosen will evolve, or how fast the deterioration of the surrounding public space, noise and air pollution, will be. This could be understood as a kind of an unplanned form of equality or divine justice, in the sense that even the rich cannot really be spared from the "invasion of the riff-raffs" (a term used with a grain of salt, as it is a typical middle class obsession). It is only that the rich have certainly more liquidity, which allows them to keep on constantly moving outward to the fringes of the city, leaving behind them spaces to be occupied by the newly ascending middle and lower classes. This brings me to the next question: how long can the gated communities and walled off spaces of the satellite cities be maintained as clean and exclusive spaces, and what could guarantee their continuity? 


\section{Tale III}

\section{My exhausted and exhausting building}

I am exhausted from the significant material degradation in my daily life since I moved to the neighborhood of Dokki in February 2016, after having lived in the residential island of Zamalek. Some friends have teasingly told me that the psychological process I have been undergoing is an obvious form of a déclassement social, but such a statement would be an over-exaggeration, since countless Cairenes would immediately identify with the descriptions of material deteriorating of the urban life that I have traced in my meanderings.

It is true that this problem is not really specific to my neighborhood. One point, however, is different. The insular character of the residential island of Zamalek has certainly been much less affected by the recent spectacular urban decomposition that affected the numerous old quarters of the city. After January 2011, the Zamalek residents turned out to be for sure better organized through the association they created and its Facebook account that circulates valuable information on sales, gatherings and collective organizing for cleaning streets, cutting trees, the timely problem of accumulating garbage and how to collect it in a well-managed way and the attempts at restraining the chaotic mushrooming of cafés at the expense of residences. But above all, the Zamalek Association proved to be quite efficient at organizing public events at the Fish Garden over the past few years, which entailed bringing together musicians and artists, and organizing spaces for sales of books, crafts, and arts.

The communal work of Zamalekites through this association which emerged after the January revolution became the target of attacks by official circles and the media. Its residents were disparaged as the rich "bourgeois", often publicly being attacked as 'egoists' for not allowing the future metro line to pass through the middle of the island, right through the very narrow street of Ismail Mohammed Street, (and incidentally revealing how impractical the metro line will be). The skirmishes between the residents of Zamalek and the regime revealed how complex civil initiatives can be since the metro line will be seriously affecting the old, and by today's standards, historical buildings of Zamalek, like the Șidqī buildings. Yet, regardless of whether such a project is or is not justifiable, there are certainly issues that go beyond the question of the bourgeois class interests; the questionable ecological sustainability of such a project, and the uncontrollable occupation of public spaces, and the multiple forms of pollution that would follow. One thing is clear, the association has clearly revealed the impact of the revolution had indeed an impact in opening new paths for collective work (ironically, working well for the better off) on the local neighborhood level on questions regarding garbage collection and the serious challenge of reordering public space. ${ }^{8}$

Having said that, the building into which I moved to in Dokki is an interesting case in point of the class mobility of a quarter that once witnessed a particular magnificence but has totally degenerated into decadence, due to the fact that its previous residents have left

8 For the controversy related to the Zamalek Association, see EL KHAWAGA 2014. 
for better neighborhoods or satellite cities. They were replaced by newcomers, not without wealth, but perhaps from the lower middle classes, with clearly different life styles. The majority of the residents of my building are old, and over sixty years old, which explains why they are mostly conservative. It has been practically impossible to get them to agree on anything, least of all to organize any collective work to improve the infrastructure of the building. Meanwhile offices and commercial activities have invaded the residential spaces, leading to an open antagonism to the very notion of privacy.

Like the majority of the old quarters in Cairo, Dokki decomposed because of the invasion of unregulated and chaotic commercial activities and shops which occupy almost all the first floors of countless buildings. These include popular coffee shops and, above all, the roving street vendors who cater to the poorer publics of the many popular cafés and shops Year after year, wonderful but often decaying villas, probably disappear due to multiplying disputing heirs and familial greed to be replaced by frightening, cheaply constructed high rise buildings. This seems to be the predicament of almost all the old gentrified quarters of Cairo.

Since the mid-nineties, the district has changed radically, and even more so after January 2011, as if chaos has become the dominant and uncontrollable state of all Cairo. The endless problem of the piling garbage resulted from the long absence of the garbage collector in my street, and it became uncontainable after January 2011 — not to mention of the uncollected heap of filth in the two stairwells of the building.

The public school across from my building, which starts at about 8 o'clock, with classes ending around 3 o'clock, plays extremely loud amplified Arabic films music every day. The amount of rubbish the students produce is spectacular, and it is mostly swept under two buses, parked permanently in front of my street. Every day we hear many of Su'ād Husnī’s film songs followed by some eccentric English songs by a Muslim American convert about how beautiful Islam is, which the children have to repeat by screaming behind the amplifiers. Alternating classes of children constantly belly-dance for almost six hours at the tiny entrance court of the school. The court is so tiny is the court of the school because the larger part was probably sold out to a private investor, and the space was distorted by a huge unfinished concrete building of some fifteen floors. It has remained deserted for more than a decade, a phenomenon not uncommon in Cairo. It is easy to speculate that either it has a serious defect or there are problems with the proprietors.

Quite often, too, many mothers are competing to penetrate the entrance door while waiting in the street to meet their children as they come out. When the students leave the school, the street is caught in a general panic, if not a paralysis, between traffic jams, the desperate mothers, the roving peddlers, the employees of the numerous banks and government offices, and the double or triple parking.

Actually, the incessant, highly noisy belly-dancing in the school could be a rich material for a surrealist film, which could be nicely shot from my fifth floor living room. However, it also means that I cannot possibly sit or work in any part of my flat and wait until the evening. But work is impossible then as well because of my upstairs floor neighbours, a hostel for Palestinian girls (some fourteen female students, almost all registered at Cairo University) who also love to belly-dance until early dawn. In fact, the director of the hostel, Madam M., an elderly, well-intentioned Palestinian woman, seems to be quite strict in not allowing the young ladies to go out in the evening. Nor are they 
allowed to receive male relatives in the hostel, which means that they stand outside in the corridor of my floor when they receive visits from their male cousins. And last but not least, the television being one of their main form of entertainment, this has resulted into escalating fights about noise.

Lawlessness prevails on all levels, among neighbours and between the bawwāb (the building keeper) and the garage keepers and constant fights lead to anonymous parties causing flat tires on some cars, or to garage keepers stealing objects from other cars. But no one dares to confront the family of the garage keepers because they are powerful and can resort to violence. Umm Tāmir, the garage keeper, who is a strong, stout baladi (working class/popular) woman in a black galläbiyyah (long robe), has squatted some four empty rooms on top of the garage, which were meant to be storing rooms for the owners of the building. Two of these rooms entail two beds and a sofa in which Umm Tāmir (spends quite a lot of time). Here again, no resident dares confront her about the squatting.

We have had quite a few endless and extremely tiring meetings in preparation for forming an ittiḥād al-shāghilīn (a building residents association). ${ }^{9}$ In these meetings, the topic of evicting Umm Tāmir has been often brought up. However, none of the residents has had the courage so far to undertake any action against her and her sons. Umm Tāmir, now a grandmother, has raised four boys on her own, two of whom spent quite some time in jail for taking part in violent beatings and street fights at the corner of our building. This has definitively given her not only material but symbolic strength in her further control of the street. Then, Umm Tāmir decided to like me because I immediately understood that I would be better off as her friend than foe. I keep a warm relationship with her sons, who have been socially stigmatized by the middle class residents of the building. There is a Robin-hoodish element about her in the way she would defend the garbage collector and the sons of the housekeeper, i.e., the weakest character of the neighborhood.

Umm Tāmir, does not live in the building because she owns an entire building elsewhere, but she can be seen every day occupying a chair, right in front of the entrance of the garage, deciding who can and cannot park in the entire street which is filled in any case, with school buses and double-parked cars. It goes without saying that Umm Tāmir truly controls the street through her networks and her friendship with the shop owners in my building. I am fortunate not to own a car, but I am an eyewitness to constant loud shouting and skirmishes in the street and on our stairs between Umm Tāmir and her numerous enemies among the new residents who have purchased flats during the last decade.

Half of my building has been turned into substandard offices. The flats have been registered as tigāri (commercial) spaces, which means that numerous employees come and go constantly all day, even as late as 10 o'clock, in the evening on certain days of the month. Once a month, the numerous female employees come to pick up their salary, which means that after their departure, the entire entrance is littered with rubbish and chewing gums. It is quite normal to find coffee and tea spilled, and cigarettes butts are thrown on the finelooking but quite old marble stairs. While the bawwāb (housekeeper) and his two sons are

9 This attempt at creating a residents association was quickly destroyed by one of the residents, who was in constant disputes with two other residents on issues of water and electricity bills and other public utilities.

$J A I S \bullet 16$ (2016): 234-252 
constantly scolded for not cleaning the entrance and stairs enough, no resident really wants to pay him a proper salary.

On the third floor, two flats have been turned into a franchise for a French perfumes and make-up company. They are owned by a well-to-do Șa ${ }^{\mathbf{i}} \mathrm{d} \overline{1}$ (Upper Egyptian) businessman. The owner of the company, a truly honest person, has committed himself to collect money from each resident for the collective electricity and water bills since he owns three flats. His secretary, Madame M., an astute and thorough accountant, who has been constantly chasing every single resident to pay his dues of £E 120 per month (which would also include the bawwāb's salary), has meanwhile lost stamina after several skirmishes with the tenants. After all, this is not her job, she often told me. She is only doing us, the residents, a favour. She does not see why she should be insulted or humiliated daily by the residents for just a few pounds. Furthermore, the owner of the company was kind enough to allow the many meetings of the residents to take place at his office. However, over time, he too became exhausted from some neighbours' tenacity in refusing to pay the collective water and electricity bills for the elevator and the entrance door. So he has decided to pull out of the association avoiding the residents' meetings under the pretext that he is constantly traveling.

Meanwhile, the owner of the company and his numerous employees sustain an open and fierce war with the bawwāb and Umm Tāmir. Umm Tāmir seems to excel day after day in the art of blocking the cars of the perfume company owner, his son, and the employees. The employees have thus learned how to park quite far away to avoid her fierce behaviour. But these tactics work both ways: some of the employees and the owner's son have learned to replicate Umm Tāmir's tricks and block the other cars in order to make Umm Tāmir's life with her parking clients even more difficult. Through these progressively sophisticated blockades, my harmless and extremely well-mannered neighbors on the next floor have ended up having their cars blockaded too. How unfortunate it is to see them being involved in endless fights and losing their temper every other day!

The perfume company owner stopped paying any salary or communicating with the $b a w w \bar{a} b$ housekeeper too, after a huge fight for a reason I failed to grasp. "Our bawwāb and the garbage collector are richer than you and me... The garbage man makes money with garbage, so why pay him?... Besides, we have no real garbage, and our maids take it downstairs," This is what I heard from one of my newly-arrived neighbors who refused my proposal to raise the salary of the garbage collector from £E 5 (not even half a dollar per month) to £E 20. Bear in mind that, this is a retired businessman, who owns a car and employs a chauffeur and various other servants.

Two sides of the garage and the entire entrance facade have been transformed into numerous small shops. There are six shops at the front selling clothes, school bags, shoes, and sportswear, and an extremely filthy and abominable café that closed down recently, and a small supermarket. The café closed down last year after its owner, another Șa ${ }^{\top} \overline{1} \mathbf{1}$ millionaire, had a violent fight with the tenant who failed to pay the rent. We are told that the millionaire, theatrically, shot him in the leg in front of everybody in the street. This melodramatic Hollywood scene apparently frightened and intimidated all the residents. This millionaire owns about four flats in the building and never pays any public utilities, elevator maintenance, electricity, or water bills which accumulate in the thousands per month. Strangely enough, nobody ever spoke of any police interference; the culprit was 
never punished, because the owner is obviously influential. This also explains why no one wants to confront him by creating a legalized Residents' Association as some of the residents insisted in the meeting, it would be a lost cause.

The shopkeepers hang around in the street the entire day and do not seem to be doing well or selling anything, as the shops are mostly devoid of customers-except for the shop selling school bags just before the opening of the schools in September. There is one tiny clothes shop that seems to me to be a cover-up for some other activity, although I am not really sure what it is. The shopkeepers excel at registering every single movement on the street [social control]. They have their chairs all lined up in front of the entrance door of the building and they often inform me gently who has come into or out of the building (the postman, the collector of electricity bills for example, my daughter and her friends, or my own friends who have lost their way) and when.

These tiny and apparently useless shops produce an endless amount of cartons and boxes that are profitable for the garbage collector, but this waste would certainly not make him rich. During the first years after the Revolution, the garbage collector almost stopped coming altogether. Only last year, when I made a deal with him to pay him £E 50 per month provided he regularly cleans all the stairs, that he did start coming every second or third day. The reason for his infrequency was not only the fact that he was not properly paid by the residents, but also that he has to rent out a truck and usually lacks the cash, unless he can be sure of collecting the cartons/boxes of the shops that would cover up for the cost of the other residents' waste.

Would one define my neighbor's reaction towards the garbage collector as a pure form of class discrimination? Not only that, the garbage collector is a Copt, which makes me wonder if it is not a typical Muslim middle-class religious racism? Only three residents followed my initiative of paying the garbage collector after the pile of garbage reached gargantuan dimensions. I ended up hiring a small truck with professional garbage removers who took away some thirty large sacks of accumulated garbage from the back stairs. It costs me £E 500 plus an entire lost day of work. But no other resident wanted to contribute to the payment of the removers.

The problem with the commercial offices of the building is their abuse of elevators as if it were a vendetta, a collective endeavor to destroy this poor antiquated moving wooden box. Only if a terrible accident were to occur, perhaps that would enough of a reason for the residents to take action. ${ }^{10}$

\section{The fifth floor co-working space}

An Internet café, no, let us be precise: a "co-working space" for young people, has opened a year ago on my floor, across from my flat on the fifth floor. Some fifty to seventy or more visitors come on a daily basis, and remain until midnight. They socialize and hang

10 In fact, in November 2016, the elevator fell down, while two employees from the perfume company were inside. Though being seriously traumatized, fortunately, they were not hurt. While the owner of the company banned his employees to use the elevator, some neighbours remain in denial of the incident. They insist that no collapse occurred. It is only a matter of how one perceives reality, some would say. While the Internet café users continue to carelessly use and abuse the elevator, I have ceased to use it. 
around in the corridors with extremely loud laughter, chatting and constant mobile phoning. They are so loud that I can no longer sit in my living room without hearing clearly everything they say and do. The visitors do their best to not only further ruin the antiquated moving wooden box, the poor elevator, but these publics also produce regularly a gripping amount of rubbish. I should be tolerant towards youth, since we had a revolution which I support; but these visitors are not only noisy, they also litter the stairs with endless rubbish. The stairs are made of old, beautiful marble, but it seems that anything antique-looking, is worthless not modern enough and has to be abused. Perhaps, a not modern enough building would justify littering.

My floor has turned into a theatre of constant power struggles over space, with young girls and men hanging around in the corridors. They love to leave hand and shoe prints everywhere on the walls of the corridor, which I painted twice. The poor plants I have put in the corridor have been ruined too, and some have disappeared, not to mention the rubbish I have to pick up daily between the poor sick plants.

Time and again, I wonder whether Cairo is a unique in having become a place where it is an acceptable pastime to spit, litter and write in its elevators. No one wants to believe that the elevator will soon break down, but no one really cares. "Be optimistic and it will not collapse," says Mr. M., the director of the co-working space who apparently has been trained by an NGO in dialogue and tolerance and how to speak softly to people. But he, too, seems reluctant to pay the $b a w w \bar{a} b$ the salary I had proposed after a long struggle with the various residents. This so-called decent salary is namely £E 100 (less than $\$ 9$ a month), whereas a cappuccino at the Cilantro café opposite to my building costs $\mathrm{E} \mathrm{E} 25$, i.e., or one fourth of the would-be "decent salary". As I keep reminding my neighbors when the littered plastic cups from these expensive cappuccinos are constantly found littering the antiquated moving wooden box, that it is logical that the bawwāb's son was tempted to steel a play station from their office when they employed him as a cleaner.

Meanwhile, living in this building for less than a year, has turned me into a melodramatic theatrical character. When the bawwäb's son cleans the stairs and it is instantly littered in no less than an hour, I take the liberty of shouting with all my strength playing with the powerful acoustics of the stairs that the times of slavery are over. Often, too, I would stick a paper on the entrance door of the co-working space, stating that the son of the baw$w \bar{a} b$ is not an Abyssinian slave, or I would collect the cigarette butts from the stairs and throw them on their desks. But to no avail. They think I must be a lunatic since I clean the public stairs by myself, while I have never seen any of those youngsters picking up a broom. No cleaning, lest because physical work is a humiliating task fit only for maids. Each fight I have with my neighbour, smiling-trained by some banal NGO, Mr. M. ends up denying that this constant noise and littering are a violation of my own space. After almost six months of talks and negotiations about the urgency of putting out trash baskets or removing these, Mr. M. still finds it more practical to litter the stairs than empty the baskets, because complains that his "bell boys" - a term he is proud to use in English since he seems to have just learned it his "bell boys"- keep on disappearing one after the other. After firing so many useless "bell boys", Mr. M.'s soft and trained voice turned to be eventually one of the main reasons why my aggressive instincts kept on the rise, until I completely lost my temper and started screaming like mad in the stairs on a regular basis. I am now ready to call in the police to shut this place. Gone are the days when I cared if whether 
I was counted to be among the $f u l \bar{u} l$, if I would have undertaken an action against youth. But their presence is becoming unbearable.

\section{Chewing-gums everywhere}

After all, it's all in our heads. "If you don't notice the chewing gums sticking to the stairs, it won't exist, but if you keep on noticing it too much, it is because you have lived too long in Germany, Madam, you tend to focus on details which we never see," as my Mr. M. keeps on telling me, laughingly. That is why no one sees the accumulated black mud in between the stairs. After having spent days with the bawwāb's son removing the sticky blackened gums from the floor, and having hung so many warnings on the walls of the entrance hall about the horrid gums, the inventive youth started sticking their gums on the iron bars on top of the stairs. It is cleaner this way, right?

If you tell the people to take the stairs, because the elevator is about to fail, they take it as an affront to their pride that you have offended their masculinity, or femininity-cumchastity. How dare you humiliate them with further physical endeavour such as going down the stairs when there is an elevator? When they noticed that I started threatening them, some of the customers started to take the elevator to the fourth floor and then the stairs to the fifth, knowing that I am observing them at the entrance of the co-working space. When the electricity bill for public utilities was raised to £E 2000 , Mr. M. refused to pay his share, for how could the residents prove that his customers are the main consumers? How to take matters lightly? My nightmarish building is another "dark comedy" 11 among so many others encountered in Cairene daily life.

\section{Tale IV}

\section{The army's involvement in public life and real estate}

From il-Gēsh wil-sha'b 'ìd wăhdah (Army and People hand in hand) to Yasqut, yasqut hukm al-'askar (Down, down with the rule of the military), to Kammil gamilak (Return your favour), a slogan in support of Sisi's campaign for the presidency. Today the voices of civil society, which backed the Revolution, find themselves entrapped in the unresolved paradox of being cornered between two competing counter revolutionary forces, that is to say, the military establishment and the Muslim Brotherhood. These two competing forces, which ended up in an open and declared war, culminating in 2013, ironically share certain elective neo-liberal and conservative affinities. They also converge on questions of 'public morality' and religious intolerance. It is no coincidence that the question of censorship and the banning of so-called morally decadent, literature labeled then as "pornographic" or "irreligious", and the recent enhancing of the law of blasphemy laws had their seeds planted already under the rule of Sadat, then Mubārak. It continued under Mursī and goes on under the military as a constant flow of one and the same logic of control.

11 I am referring here once again to Elena CHITI's article, "A Dark Comedy: Perceptions of the Egyptian Present between Reality and Fiction," in this special issue. 
The two major forces, the Muslim Brothers and the military establishment, seem to be equally entrapped in repertoires, and even becoming mirror images become mirror images of each other, depicting the continuity of the mindset of the ancient regime of Mubārak. This explains the impasse that resulted from the discord among intellectuals, secularists and civil society activists regarding the army's interference and the unfolding massacre of Rābi'ah al-'Adawiyyah in August 2013, but which cannot be analyzed in this brief article.

There is much controversy regarding the army's involvement since the 28 January when the tanks took to the streets and encircled Tahrīr Square before Mubārak's ouster, supposedly to protect the protesters from the thugs of the Mubārak regime. ${ }^{12}$ Most probably, Mubārak's ouster would have been unthinkable had the armed forces not received the green light from Washington to remain neutral towards the Revolution. If a form of "fraternization" between the "people" and the army, as Neil Ketchley argues, ${ }^{13}$ took place in the early days of January 2011, there is a myriad of readings and interpretations regarding the ambiguity of the army's position and their deteriorating popularity as time went by.

The iconic images that circulated globally in 2011 must be recalled here, images of the protesters sleeping under the army tanks, or the insults and anti-Mubārak slogans that were written on the army tanks or the elderly women kissing soldiers in Tahrīir after Mubārak's departure. Looked at in another way, however, it was the rather antiquated army tanks (completely unpractical for conducting any urban warfare) that took over and encircled the television building in Maspero street on the $28^{\text {th }}$ of January, that could be interpreted as a rather symbolic repertoire of a déjà $v u$ scene, recalling to the former Free Officers taking over the broadcast station to announce the July 1952 coup/revolution when they overthrew King Fārūq.

However, the image of the army continued to decline after the take over by the SCAF (The Supreme Council of the Armed Forces). Numerous incidents unfolding over time such as the attacks on the protesters on Tahrīr in March 2011; the torturing and undertaking of virginity tests on female protesters; then the Maspero massacre in October 2011; the Ultra's Ahli massacre in Port Said; and then the violent incidents of Muhammad Mahmmūd Street in November and December 2011 — all pointed to the fact that the army was clearly siding with the counter-revolution. Observers at the time interpreted the early actions of the army in January as falling on the side of the protestors. But the army's position is explainable not so much in term of aspiration for freedom and democracy, but rather as a golden opportunity to get rid of Gamāl Mubārak and his entourage of crony capitalists,

12 As an eye-witness on the night of the famous Battle of the Camel in Tahriir in February 2011, watching it from a flat overlooking the Square, I recall that around 5:30 pm a large crowd of the thugs of the regime came from Tahrīr Square and Țal'at Harb Street heading towards the square. They threw Molotov cocktail bombs. They were shooting live ammunition towards the protesters and they were burning anything that was in their way, particularly cars, which they would then turn upside down. One could clearly see that the army tanks did nothing to stop the burning of the cars or to fight back against the thugs. The anti-Mubarak protestors could only defend themselves by barricading the checkpoints with some metal shields that were collected from the construction site of the former Hilton hotel, which was being renovated. Their only weapon were stones, which they collected and threw. The streets were in real chaos and many people were wounded. I also recall phoning a friend who had gone to all demonstrations since the $25^{\text {th }}$.

13 KetChLEy 2014. 
whose economic interests were clashing with the army's parallel control of a significant proportion of the economy. However, in 2013 Mursī's ouster went hand in hand with the revival of further nationalist sentiments through the portrayal of al-Sīsī's as the nationalist hero who opposed intercontinental Islamic networks. He was depicted as the born-again Gamāl 'Abd al-Nāșir who would rescue the nation from foreign machinations, alluding to the Muslim Brothers' extra-territorial connections. And these nationalist sentiments seem to have worked quite well for the past few years.

One thing about the military has been evident since 2011: the public visibility of the military in the urban remaking of cities after January 2011 became more obvious than ever. So many of the army's actions remain in the collective memory as vivid images of the mounting militarization of daily urban life: the presence of the army tanks in the streets of the center of town (constantly appearing, disappearing, and reappearing from 2011 until 2014); the erection of concrete walls as barriers between the protesters and police forces; the piercing and demolition of these isolating and paralyzing walls by the citizens (see fig. 7); the blockading of entire areas for security reasons; the urban wars; the vertical control of the city through the presence of helicopters at peak moments in

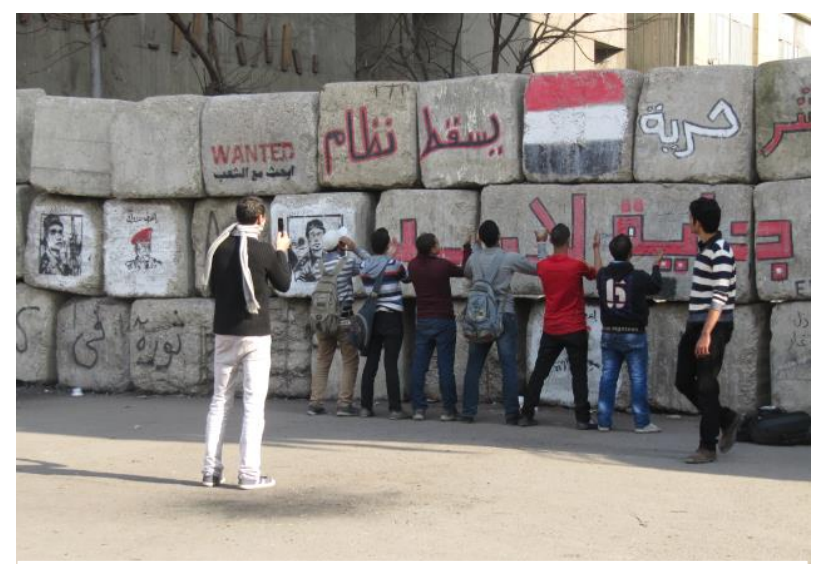

Fig. 7: Block wall Muḥammad Maḥmūd. Captured Dec. 15, 2011. It appears like these young men are praying in front of the wall.

Tahrir in January 2011 and on 30 June 2013; the numerous attacks and retreats and killings by the police forces in various busy, central streets of the city between 2011 and 2013; the tear gas, resulting in numerous deaths and epileptic attacks; the emergence of newly created paramilitary troops parading in the city; and finally the Rabe'a al-'Adawiyya massacre and the increasingly militarized terrorist attacks by the Islamists. These kinds of events turned into a quotidian exercise which no longer astonished anyone. The international policies of the "war on terror," and the multiplication of gigantic concave walls around official buildings and embassies all over the city in 2015 and 2016-reminiscent of the Green Zone in Baghdad - all of which remain vivid images of the mounting militarization of daily urban life. These created collective habits on how to deal, circumvent, or resist under such circumstances.

Zeinab Abul-Magd's crucial work ${ }^{14}$ is perhaps among the first studies to have pointed to the paramount role of the army's involvement in the current economy and why their activities have been kept opaque from the public sphere. Essentially, again according to Abul-Magd, the armed forces have been financially involved for many decades, in an esti-

14 Abul-Magd 2016. 
mated of $25 \%$ to $40 \%$ of Egypt's economy. These include some mega-projects, including large factories of food and beverage industries, running cafeterias and gas stations. This would explain the two parallel competing poles and why the army opted to depose of $\mathrm{Mu}-$ bārak and his son's entourage of crony capitalists who constituted a parallel competing elite to the army's economic interests.

But, above all, the military has been able to manage huge amounts of land. Egyptian law allows them to obtain of any land for lucrative commercial purposes. Most significant is the army's visible involvement in gargantuan real estate projects through controlling desert land to be developed with joint venture transactions in lucrative financial speculation. This became all the more evident when the Armed Forces Land Projects Agency recently took over the supervision of the New capital City and Sheikh Zayed, extending to some 16,000 acres. ${ }^{15}$ A year earlier Sisi announced the military's involvement in a 40 Billion $\$$ joint project for Low income housing with the Arabtec Company from the Emirates. ${ }^{16}$ The Cairobserver informs us that in 2014 the Defense Ministry signed a contract with the mega-company based in the UAE Emaar, to construct a huge Emaar Square that would include the largest shopping centre in Uptown Cairo, contrasting the neo-liberal market-oriented Dubai as a model against Tahrīr. Yet, a market economy is envisaged and dreamt of only under the authoritarian military rule under which the army becomes the major manipulator of vast amounts of land and can market it as it wishes without providing any transparency in the transactions. ${ }^{17}$ Once again, this is not new, market economy and neo-liberal dreams and authoritarian militarism work together very well.

To conclude, many keep on raising the following unanswered questions: how long can the military regime remain in control of the situation? And, is the regime really in control of the escalating, acute economic crisis caused by the conditional reception of the World Bank loan, which led to the floatation of the Egyptian pound, resulting into the loss of almost $80 \%$ of its value in just a few days after the implementation of the floatation? How long can the regime's credibility last with the perpetration of identical repertoires of violence ${ }^{18}$ and violations of human rights, in a harsher way than under Mubarak $?^{19}$ And when the commemoration of the martyrs of the revolution remains consciously neglected? How long can the discourse of the military "order" be sustainable when precariousness and daily endurance are tied to cruel survival strategies? And when chaos is becoming the rule? There is no doubt that the spectre of a forthcoming violent explosion is in the air. Yet, the collective fear prompted by the neighbouring decomposing states of Syria, Yemen, Iraq and Libya, remains one main reason why many would still insist: "we are still fortunate to have avoided a civil war".

15 Cf. SAWAF 2016.

16 SABA 2014.

17 N.N. (Cairobserver) 2014.

18 Regarding the point of repertoires in the political culture see ABAZA 2016.

19 On the point of why the regime is undertaking harsher measures towards liberties and human rights, see the recent interview with Hazem KANDIL 2016. 


\section{References}

ABAZA, Mona. 2016. "Violence, Dramaturgical Repertoires and Neoliberal Imaginaries in Cairo." Theory, Culture, Society, 33/7-8 (2016): 111-135.

ABAzA, Mona. 2014. "Post January Revolution Cairo: Urban Wars and the Reshaping of Public Space." Theory Culture Society, 31/7-8 (2014), <http://journals.sagepub.com/doi/abs/10.1177/ 0263276414549264> (published online 30 September 2014).

'Abd al-'Azīz, Basma. 2014. "Taḥt al-tahdīd" (translation from Arabic: Blackmail), 8 November 2014, <http://www.shorouknews.com/columns/view.aspx?cdate $=08112014 \& i d=8972 \mathrm{e} 8 \mathrm{f} 3-\mathrm{a} 153-$ 46f4-b8a4-698c427e22be> (retrieved 20 November 2014).

AвоU El NAGA, Shereen. 2015. "Beyond memory: Exploring nostalgia after the Arab revolutions." Ahramonline, Sunday 13 December 2015, <http://english.ahram.org.eg/NewsContentP/4/ 173293/Opinion/Beyond-memory-Exploring-nostalgia-after-the-Arab-r.aspx> (retrieved 6 January 2016).

ABul-Magd, Zeinab. 2016. "The Army and the Economy in Egypt." Midan Masr, Sunday, 7 August 2016, <http://www.midanmasr.com/en/article.aspx?ArticleID=222> (retrieved 3 September 2016)

AREndt, Hannah. 1990 (repr.). On Revolution. Penguin Books. First Published by Viking Press, USA, 1963

El Khawaga, Dina. 2014. "The Zamalek metro station: 6 lessons on citizenship." Mada Masr, 9 January 2014, <http://www.madamasr.com/opinion/zamalek-metro-station-6-lessons-citizenship> (retrieved 5 June 2016).

HaRveY, David. 2008. “The Right to the City.” New Left Review, 53 (Sept.-Oct. 2008): 23-40.

KANDIL, Hazem. 2016. "Interview: Sisi’s Egypt”. New Left Review, 102 (Nov.-Dec. 2016): 5-40.

Ketchley, Neil. 2014. "The People and the Army are One Hand." Comparative Studies in Society and History, 56/1 (2014): 155-186. KInGSLEY, Patrick. 2014. "How did 37 prisoners come to die at Cairo prison Abu Zaabal?" The Guardian, 22 Feb. 2014, <https://www.theguardian.com/ world/2014/feb/22/cairo-prison-abu-zabaal-deaths-37-prisoners> (retrieved 5 January 2017)

[N.N.] 2014. "From Tahrir Square to Emaar Square." Cairoobserver, 23 February 2014, <http:// cairobserver.com/post/77533681187/from-tahrir-square-to-emaar-square - .V6isi4dUTGI> (retrieved 25 March 2014).

NoRA, Pierre. 1989. "Between Memory and History: Les lieux de Memoire." Representations, 26 (Spring 1989, Special Issue on Memory and Counter-Memory): 7-24.

OAKFORD, Samuel. 2014. "Egypt's Expansion of the Suez Canal Could Ruin the Mediterranean Sea." Vice News, 9 October 2014, https://news.vice.com/article/egypts-expansion-of-the-suez-canalcould-ruin-the-mediterranean-sea (retrieved 2 December 2014)

SABA, Joana. 2014. "The role of the armed forces in post-30 June Egypt." Daily News Egypt, 27 September 2014, <http://www.dailynewsegypt.com/2014/09/27/military-state-role-armed-forcespost-30-june-egypt/> (retrieved 25 Nov. 2014).

SAwAF, L. 2016. “The Armed Forces and Egypt's Land.” Mada Masr, 26 April 2016, <http://www. madamasr.com/sections/economy/armed-forces-and-egypts-land> (retrieved 30 April,2016 ).

(C) Mona Abaza, The American University in Cairo, Egypt

4 mona.abaza@gmail.com

JAIS • 16 (2016): 234-252 